\title{
Kinematic assessment of rock slope stability at Obajana and Ewekoro quarries
}

\author{
Saliu Muyideen Alade ${ }^{1}$, Shehu Shaib Abdulazeez ${ }^{2}$ \\ ${ }^{1}$ Department of Mining Engineering, the Federal University Technology, Akure Ondo State, Nigeria \\ ${ }^{2}$ Department of Mineral Resources Engineering, Kogi State Polytechnic, Lokoja, Nigeria
}

\section{Email address:}

saliuma4u@yahoo.com (S. M. Alade), shehuthefirst@yahoo.com (S. S. Abdulazeez)

\section{To cite this article:}

Saliu Muyideen Alade, Shehu Shaib Abdulazeez. Kinematic Assessment of Rock Slope Stability at Obajana and Ewekoro Quarries. Earth Science. Vol. 3, No. 2, 2014, pp. 34-41. doi: 10.11648/j.earth.20140302.11

\begin{abstract}
The research work assessed the stability of rock slopes for optimum exploitation of limestone deposits at Obajana in Kogi State and Ewekoro in Ogun state. Geological mapping was carried out to measure the orientations of discontinuities. The orientation data obtained were plotted on stereonets to determine pole concentration and major joint sets using Dips 5.0 software from Rocscience. Two joint sets were identified in Obajana with orientations of $72^{0} / 089^{0}$ and $88^{\circ} / 221^{0}$ while three joint sets with orientations of $61^{\circ} / 048^{0}, 16^{\circ} / 280^{\circ}$ and $90^{\circ} / 140^{\circ}$ were identified in Ewekoro quarry face. The Dips software was further used to perform kinematic analyses for toppling, planar and wedge failures for each of the faces investigated. The friction angles for the kinematic analyses were obtained using Roclab 1.0 software (Rocscience, 2002). The results of the analyses show that toppling failure cannot occur in Obajana while planar and wedge failures may occur. The three failure modes (toppling, planar and wedge) were identified in Ewekoro.
\end{abstract}

Keywords: Joint Sets, Pole, Quarry Face, Planar Failure, Wedge Failure, Toppling Failure

\section{Introduction}

Assessment of slope stability and excavation method of rocks is an important problem in mining and civil engineering. This holds for both the design and construction stages. A number of methods are being used for the assessment of slope stability and excavation method (Hoek and Bray, 1981; Goodman, 1989; Pettifer and Fookes, 1994). Kinematical, limit equilibrium and numerical analyses are generally preferred for the evaluation of rock. Kinematical analysis refers to the motion of bodies without reference to the forces that cause them to move. Equilibrium analyses consider the shear strength along the failure surface, the effects of pore water pressure and the influence of external forces such as reinforcing elements or seismic accelerations. On the other hand, numerical analyses such as finite element and distinct element methods are performed to confirm results of kinematical and equilibrium analysis (Gurocak et al., 2008)

The term slope stability may be defined as the resistance of inclined surface to failure by sliding or collapsing (Kliche, 1999). According to Eberhardt 2003, the main objectives of slope stability analysis are finding endangered areas, investigation of potential failure mechanisms, determination of the slope sensitivity to different triggering mechanisms, designing of optimal slopes with regard to safety, reliability and economics, designing possible remedial measures, e.g. barriers and stabilization.

All mining operations require excavation of rocks which results in exposing rock slopes. It therefore becomes an economic and safety imperative to ensure the stability of the slopes to maximize profit and to prevent losses as well as other likely effects of slope failure which may include damages to personnel, machinery, equipment, building and other infrastructural facilities.

For reducing to a minimum the amount of waste rock which has to be excavated in recovering an ore body, the ultimate slopes of the mines are generally cut to the steepest possible angle. Since the economic benefits gained in this way can be negated by a major slope failure, evaluating the stability of the ultimate slopes is an important part of open pit planning (Hoek and Bray, 1981).

An optimum slope design is the one that fails soon after the end of operations. The common design requirement for rock cuts is to determine the maximum safe cut face angle compatible with the planned maximum height. The design 
process is a trade-off between stability and economics. That is, steep cuts are usually less expensive to construct than flat cuts because there is less volume of excavated rock, less acquisition of right-of-way and smaller cut face areas. However, with steep slopes it may be necessary to install extensive stabilization measures such as rock bolts and shotcrete in order to minimize both the risk of overall slope instability and rock falls during the operational life of the project (Wyllie and Mah, 2005). They submitted that in open pit mining, the optimum slope design is usually one that maximizes overall slope angles and minimizes the amount of waste stripping. At the same time, it must effectively manage the risk of overall slope instability, and provide for safe and efficient movement of personnel, equipment and materials during mining operations.

According to Hoek and Bray (1981), while the overall slopes are clearly important in terms of the economics of the entire mining operation, the stability of individual benches is usually a matter of more immediate concern. This is because slope failure in a bench carrying the main haul road or which is adjacent to a property boundary or an important installation can cause severe disruption to the mining programme. In such relatively small failures, lives can be lost and costly equipment damaged.

\section{Mechanisms of Rock Slopes Failure}

Stability assessment using Kinematics method refers to the motion of bodies without reference to the forces that caused them to move. Different types of slope failure are associated with different geological structures and it is important that the slope designer be able to recognize potential stability problems during the early stages of a project (Wyllie and Mah, 2005). The geometrical relationship between the geologic features and the orientation of the overlying slope determines the kinematics stability of slopes (Akande and Idris, 2007). The kinematic analysis is used to evaluate modes of rock failure. There are four basic modes of rock slope failure. These are the plane failure, the wedge failure, toppling failure and circular failure. Figure 1 shows the four types of failure modes and typical pole plots of geological conditions likely to lead to such failures.

\subsection{Plane Failure}

Plane failure is sliding along single planar geological structure that dips downward at an inclination flatter than that of the overlying slope face. Hoek and Bray (1981) proposed that the following conditions must be satisfied in order for sliding to occur in a single plane:

1. The plane on which sliding occurs must strike parallel or nearly parallel (within approximately $\pm 20^{\circ}$ ) to the slope face.

2. The failure plane must "daylight" in the slope face. This means that its dip $\left(\psi_{p}\right)$ must be smaller than the dip of the slope face $\left(\psi_{f}\right)$.
3. The dip of the failure plane $\left(\psi_{p}\right)$ must be steeper than the angle of friction $(\phi)$ on this plane, unless ground water pressure exists, in which case failure can develop for $\left(\psi_{p}\right)<\phi$.

4. Release surfaces which provide negligible resistance to sliding must be present in the rock mass to define the lateral boundaries of the slide. Alternatively, failure can occur on a failure plane passing through the convex "nose" of a slope.

\subsection{Wedge Failure}

Wedge failure is the sliding along a line of intersection of geological structures where the line of intersection points downwards (plunges) at an inclination flatter than that of the overlying slope face. According to Hoek and Bray (1981), the geometrical conditions that must be fulfilled for wedge failure to occur are:

1. Two discontinuities must strike obliquely across the slope face.

2. The plunge of the line of intersection must "daylight" in the slope face. That is, apparent dip of the slope $\left(\psi_{f i}\right)$ must be greater than the plunge of the intersection line $\left(\psi_{i}\right)$.

3. The plunge of the line of intersection $\left(\psi_{i}\right)$ must be significantly greater than the angle of friction, unless ground water pressure exists, in which case failure can develop for $\left(\psi_{i}\right)<\phi$.

\subsection{Toppling Failure}

Toppling failure involves rotation of columns or blocks of rock about some fixed base. Closely spaced, steeply dipping discontinuities sets that dip away from the slope surface are necessary prerequisites for toppling. Goodman and Bray (1976) have described a number of different types of toppling failures which may be encountered in the field and they include flexural toppling, block toppling and block-flexure toppling.

\subsection{Circular Failure}

Circular failures usually occur in soft materials such as overburden soils, highly weathered rocks or crushed waste. Failure occurs along a surface which approaches a circular shape in these materials. In the case of highly weathered rock, soil or crushed waste, a strongly defined structural pattern no longer exists and the failure surfaces is free to find the line of least resistance through the slope. The slope failures in these materials generally occur when their slope surfaces take the form of a circle (Hoek and Bray, 1981).

The conditions under which circular failure will occur arise when the individual particles in a soil or rock mass are very small as compared with the size of the slope and when these particles are not interlocked as a result of their shapes. Hence, crushed rock in a large waste dump will tend to behave as a "soil" and large failures will occur in a circular mode. 
(a)

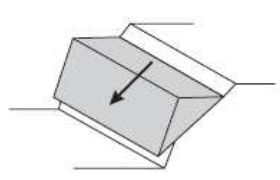

(b)

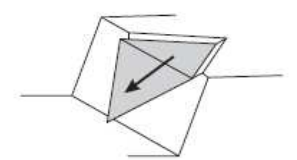

(c)

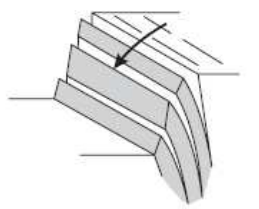

(d)

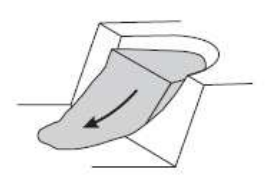

Legend
Pole concentrations
$\begin{aligned} & \text { Great circle representing } \\ & \text { face }\end{aligned}$
$\begin{aligned} & \text { Great circle representing } \\ & \text { plane corresponding to centers } \\ & \text { of pole concentrations }\end{aligned}$
$\alpha_{s}$ dip direction of sliding
$\alpha_{4}$ direction of toppling
$\alpha_{i}$ dip direction,
line of intersection

Figure 1. Main types of block failure mechanisms in slopes: (a) Planar, (b) Wedge, (c) Toppling and (d) Circular failures (Wyllie and Mah, 2005).

\section{Methodology}

\subsection{Geological Mapping}

The method used is the scanline technique. The geological mapping is aimed at identifying the structural geology of Obajana and Ewekoro deposits, by measuring the orientations of the discontinuities for stability analysis and evaluation. This is because the orientation of discontinuities relative to an engineering structure largely controls the possibilities of unstable conditions or excessive deformations developing (ISRM, 1981). The Dips and Dip directions of the discontinuities were measured with the clinometers and expressed in degrees as two and three digit numbers respectively as recommended by ISRM, 1981. The discontinuity spacings were also measured as shown in Figure 2.

\subsection{Density and Unit Weight}

The objective of the test is to measure the dry density and consequently, the unit weight of rock samples of irregular form from Obajana and Ewekoro deposits. The Saturation and Buoyancy technique for irregular rock sample was adopted and the procedures follow the standard suggested by ISRM (1981) and conform to ASTM (1994).
The saturated volume of the sample was calculated as follows:

$$
\text { Saturated Volume of Sample }=V_{2}-V_{1}
$$

Where $\mathrm{V}_{1}(\mathrm{ml})$ is the initial water level and $\mathrm{V}_{2}(\mathrm{ml})$ is the final water level in the cylinder after the immersion of the irregular rock sample.

The dry density of the rock samples was calculated using the following formula:

$$
\text { Dry density of the rock sample }=\frac{M}{V_{2}-V_{1}}
$$

Where $\mathrm{M}(\mathrm{g})$ is the oven dried mass at a temperature of $105^{0} \mathrm{C}$.

The unit weight was then evaluated using:

$$
\text { Unit weight }(\gamma)=\rho_{d} \times g
$$

where $g=$ Acceleration due to gravity $=9.81 \mathrm{~m} / \mathrm{s}^{2}$.

\subsection{Hardness Test}

The test involved the use of Schmidt impact hammer of type $\mathrm{N}$ for the hardness determination of lump rock samples. The rebound value of the Schmidt Hammer is used as an index value for the intact strength of rock material, but it is also used to give an indication of the compressive strength of rock material (ISRM, 1981).The result of the hardness test is used to evaluate the Unconfined Compressive Strength (UCS) and consequently, the Point Load Index Values.

The standard method for the Schmidt hammer test as described by ISRM (1981) and ASTM (1994) was followed.

The measured test values for the samples were ordered in descending order. The lower $50 \%$ of the values were discarded and the average obtained of the upper $50 \%$ values to obtain the Schmidt Rebound Hardness (ISRM, 1981).

The average values obtained from the Type $-\mathrm{N}$ machine was converted to Type - L readings by using the relationship established by Aydin and Basu (2005):

$$
R_{N}=1.0646 R_{L}+6.3673
$$

Where $\mathrm{R}_{\mathrm{N}}=$ Rebound Hardness value from Type $\mathrm{N}$ Hammer, and $\mathrm{R}_{\mathrm{L}}=$ Rebound Hardness value from Type $\mathrm{L}$ Hammer.

\subsection{Unconfined Compressive Strength (UCS)}

The Uniaxial Compressive Strength of the rock samples were estimated from the values of the equivalent Type L Schmidt Hammer Hardness and the density of the rock.

The UCS values were estimated by an Equation developed by Xu and Mahtab (1990):

$$
U C S=12.74 \operatorname{Exp}\left(0.02 \times R_{L} \times \rho\right)
$$

Where UCS $=$ Uniaxial Compressive Strength $(\mathrm{MPa})$, 
$\mathrm{RL}=$ Rebound Hardness value of Type L Hammer, and $\rho=$ Density of rock $\left(\mathrm{g} / \mathrm{cm}^{3}\right)$.

The UCS was used for the strength classification and characterization of the intact rock for the Mohr - Coulomb criterion for obtaining the friction angle.

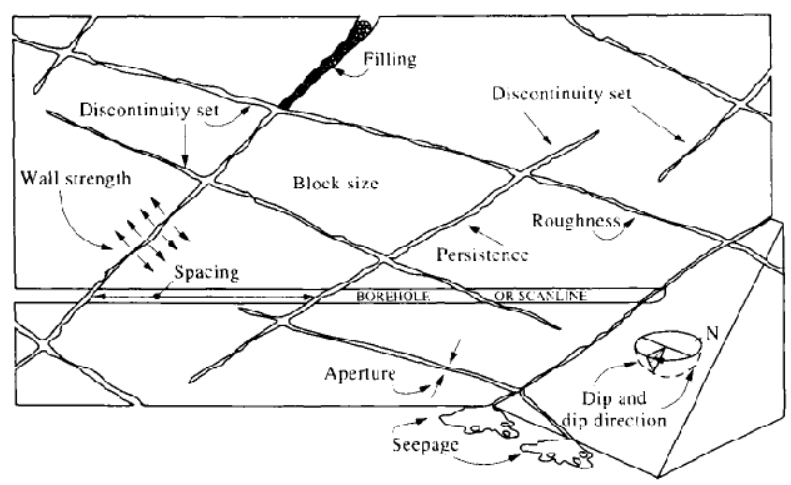

Figure 2. Geometrical Properties of Discontinuities (After Hudson, 1989).

A total number of 150 and 250 discontinuities were mapped for Obajana and Ewekoro deposits respectively which are in accordance to ISRM (1981) and Wyllie and Mah (2005). This is presented in discontinuity survey data sheet in Tables 1 and 2.

\subsection{Kinematic (Stability) Assessment}

Kinematic analyses were carried out on the stereonet to show the influence of discontinuity sets on the stability, and to indicate the type of potential failure modes. A program called Dips 5.0 developed by Rocscience was used for the kinematics analysis. A declination of $7.5^{\circ}$ was added to the dip directions of the data to correct for the magnetic declination (Rocscience, 1999).

In all the analyses, poles of less than $4 \%$ are regarded with suspicion as suggested by Rocscience (1999) unless the overall quantity of data is very high (several hundreds of poles). The friction angles were represented on the stereonet with a trend and plunge of $0^{\circ}$ and $90^{\circ}$ respectively.

For Toppling Analyses, variability cones for each of the major joint sets were generated. Because the planes cannot topple if they cannot slide with respect to one another, Slip Limits were added with dips given as the difference between the slope face and the friction angle while the dip direction is the same as that of the slope face. The variability cone for the slip limit was also drawn with a trend, plunge and angle of $90^{\circ}, 0^{\circ}$ and $60^{\circ}$ respectively. The $60^{\circ}$ cone angle will place two limits $\pm 30^{\circ}$ with respect to the dip direction of the face as suggested by Goodman (1980) - plane must be within $30^{\circ}$ of parallel to a cut slope to topple.

In the planar failure analyses, a daylight envelope was indicated to define the possible failure regions with the friction cone.

For the wedged analyses, the intersection of the major joint sets were identified with respect to the pit slope and the friction angle which defines the failure zone. In wedge, actual sliding surface or line is the most important and not the poles. Therefore the friction angle was taken from the equator of the stereonet and not from the centre. Thus it has a trend, plunge and angle of $0^{\circ}, 90^{\circ}$ and $\left(90^{\circ}-\right.$ friction Angle) respectively.

\section{Results and Discussion}

The orientations of the discontinuities in Dips and Dip directions were measured as well as the discontinuity spacing. Graphical representations of orientations of the discontinuities mapped are shown in Figures 3 and 4 in pole and contour plots. Two major joint sets were identified in Obajana quarry with average orientations of $72 / 89$ and $88 / 22$, and three in Ewekoro with average orientations of $62 / 048,16 / 280$ and 90/140. Summary of this result is shown in Table 1.

Table 1. Orientations of Identified Joint sets.

\begin{tabular}{lll}
\hline JOINT TYPE & OBAJANA & EWEKORO \\
\hline Joint Set I & $72^{0} / 089^{0}$ & $61^{\circ} / 048^{0}$ \\
Joint Set II & $88^{0} / 221^{0}$ & $16^{0} / 280^{\circ}$ \\
Joint Set III & - & $90^{\circ} / 140^{\circ}$ \\
\hline
\end{tabular}

Tables 2(a-d) are the results of density and unit weight test. Tables 3 and 4 are the summary of Density and Unit Weight results respectively. Type II deposit of Ewekoro has the highest density and unit weight values while type I of the same Ewekoro has the least.

Table 2a. Density and Unit Weight Result for Obajana Deposit.

\begin{tabular}{lllllll}
\hline $\begin{array}{l}\text { Samp } \\
\text { le }\end{array}$ & $\begin{array}{l}\text { Dry } \\
\text { mass } \\
(\mathbf{g})\end{array}$ & $\begin{array}{l}\mathbf{V 1} \\
\mathbf{c m}^{\mathbf{3}}\end{array}$ & $\begin{array}{l}\mathbf{V 2} \\
\mathbf{c m}^{\mathbf{3}}\end{array}$ & $\begin{array}{l}\mathbf{( V 2} \mathbf{V}) \\
\mathbf{c m}^{\mathbf{3}}\end{array}$ & $\begin{array}{l}\text { Densit } \\
\mathbf{y} / \mathbf{c m}^{\mathbf{3}}\end{array}$ & $\begin{array}{l}\text { Unit } \\
\text { Weight } \\
\mathbf{k N} / \mathbf{m}^{\mathbf{3}}\end{array}$ \\
\hline 1 & 71.5 & 400.0 & 427.0 & 27.0 & 2.65 & 25.98 \\
2 & 70.5 & 395.0 & 421.5 & 26.5 & 2.66 & 26.10 \\
3 & 60.4 & 380.0 & 403.0 & 23.0 & 2.63 & 25.76 \\
4 & 60.1 & 370.0 & 394.0 & 24.0 & 2.50 & 24.57 \\
5 & 65.4 & 360.0 & 385.5 & 25.5 & 2.56 & 25.16 \\
\hline
\end{tabular}

Table 2b. Density and Unit Weight Result for Ewekoro Type I Deposit.

\begin{tabular}{|c|c|c|c|c|c|c|}
\hline $\begin{array}{l}\text { Samp } \\
\text { le }\end{array}$ & $\begin{array}{l}\text { Dry } \\
\text { mass M } \\
(\mathbf{g})\end{array}$ & $\begin{array}{l}\mathrm{V} 1 \\
\mathrm{~cm}^{3}\end{array}$ & $\begin{array}{l}\mathrm{V} 2 \\
\mathrm{~cm}^{3}\end{array}$ & $\begin{array}{l}\text { (V2- } \\
\text { V1) } \\
\mathrm{cm}^{3} \\
\end{array}$ & $\begin{array}{l}\text { Densit } \\
\mathrm{y} \\
\mathrm{g} / \mathrm{cm}^{3}\end{array}$ & $\begin{array}{l}\text { Unit } \\
\text { Weight } \\
\text { kN/m }\end{array}$ \\
\hline 1 & 62.4 & 353.0 & 379.0 & 26.0 & 2.40 & 23.54 \\
\hline 2 & 69.9 & 350.0 & 379.0 & 29.0 & 2.41 & 23.65 \\
\hline 3 & 67.1 & 347.0 & 375.0 & 28.0 & 2.4 & 23.51 \\
\hline 4 & 63.9 & 343.0 & 370.0 & 27.0 & 2.37 & 23.22 \\
\hline 5 & 64.5 & 338.0 & 364.5 & 26.5 & 2.43 & 23.88 \\
\hline
\end{tabular}

Table 2c. Density and Unit Weight Result for Ewekoro Type II Deposit.

\begin{tabular}{|c|c|c|c|c|c|c|}
\hline $\begin{array}{l}\text { Samp } \\
\text { le }\end{array}$ & $\begin{array}{l}\text { Dry } \\
\text { mass M } \\
\text { (g) }\end{array}$ & $\begin{array}{l}\mathrm{V} 1 \\
\mathrm{~cm}^{3}\end{array}$ & $\begin{array}{l}\mathrm{V} 2 \\
\mathrm{~cm}^{3}\end{array}$ & $\begin{array}{l}\text { (V2- } \\
\mathrm{V} 1) \\
\mathrm{cm}^{3}\end{array}$ & $\begin{array}{l}\text { Densit } \\
\mathrm{y} \\
\mathrm{g} / \mathrm{cm}^{3}\end{array}$ & $\begin{array}{l}\text { Unit } \\
\text { Weight } \\
\mathrm{kN} / \mathrm{m}^{3}\end{array}$ \\
\hline 1 & 72.6 & 410.0 & 437.0 & 27.0 & 2.69 & 26.38 \\
\hline 2 & 65.6 & 408.0 & 432.5 & 24.5 & 2.68 & 26.27 \\
\hline 3 & 56.5 & 405.0 & 425.5 & 20.5 & 2.76 & 27.04 \\
\hline 4 & 68.0 & 402.0 & 427.0 & 25.0 & 2.72 & 26.68 \\
\hline 5 & 60.0 & 394.0 & 416.5 & 22.5 & 2.67 & 26.16 \\
\hline
\end{tabular}


Table 2d. Density and Unit Weight Result for Ewekoro Type III Deposit.

\begin{tabular}{|c|c|c|c|c|c|c|}
\hline $\begin{array}{l}\text { Samp } \\
\text { le }\end{array}$ & $\begin{array}{l}\text { Dry } \\
\text { mass M } \\
(\mathrm{g})\end{array}$ & $\begin{array}{l}\mathrm{V} 1 \\
\mathrm{~cm}^{3}\end{array}$ & $\begin{array}{l}\mathrm{V} 2 \\
\mathrm{~cm}^{3}\end{array}$ & $\begin{array}{l}\text { (V2- } \\
\mathrm{V} 1) \\
\mathrm{cm}^{3}\end{array}$ & $\begin{array}{l}\text { Densit } \\
\mathrm{y} \\
\mathrm{g} / \mathrm{cm}^{3}\end{array}$ & $\begin{array}{l}\text { Unit } \\
\text { Weight } \\
\text { kN/m }\end{array}$ \\
\hline 1 & 57.7 & 350.0 & 373.0 & 23.0 & 2.51 & 24.61 \\
\hline 2 & 67.1 & 346.0 & 373.0 & 27.0 & 2.49 & 24.38 \\
\hline 3 & 64.8 & 340.0 & 365.5 & 25.5 & 2.54 & 24.93 \\
\hline 4 & 68.4 & 330.0 & 357.5 & 27.5 & 2.49 & 24.40 \\
\hline 5 & 54.3 & 325.0 & 347.0 & 22.0 & 2.47 & 24.21 \\
\hline
\end{tabular}

Table 3. Summary of density Results.

\begin{tabular}{lllll}
\hline $\begin{array}{l}\text { Test } \\
\text { No }\end{array}$ & Obajana & $\begin{array}{l}\text { Ewekoro } \\
\text { Type I }\end{array}$ & $\begin{array}{l}\text { Ewekoro } \\
\text { Type II }\end{array}$ & $\begin{array}{l}\text { Ewekoro } \\
\text { Type III }\end{array}$ \\
\hline 1 & 2.65 & 2.40 & 2.69 & 2.51 \\
2 & 2.66 & 2.41 & 2.68 & 2.49 \\
3 & 2.63 & 2.40 & 2.76 & 2.54 \\
4 & 2.50 & 2.37 & 2.72 & 2.49 \\
5 & 2.56 & 2.43 & 2.67 & 2.47 \\
AVG & $\begin{array}{l}2.60 \\
\left(\mathrm{~g} / \mathrm{cm}^{3}\right)\end{array}$ & $2.40\left(\mathrm{~g} / \mathrm{cm}^{3}\right)$ & $2.70\left(\mathrm{~g} / \mathrm{cm}^{3}\right)$ & $2.50\left(\mathrm{~g} / \mathrm{cm}^{3}\right)$ \\
\hline
\end{tabular}

Table 4. Summary of Unit Weight Results.

\begin{tabular}{lllll}
\hline $\begin{array}{l}\text { Test } \\
\text { No }\end{array}$ & Obajana & $\begin{array}{l}\text { Ewekoro } \\
\text { Type I }\end{array}$ & $\begin{array}{l}\text { Ewekoro } \\
\text { Type II }\end{array}$ & $\begin{array}{l}\text { Ewekoro } \\
\text { Type III }\end{array}$ \\
\hline 1 & 25.98 & 23.54 & 26.38 & 24.61 \\
2 & 26.10 & 23.65 & 26.27 & 24.38 \\
3 & 25.76 & 23.51 & 27.04 & 24.93 \\
4 & 24.57 & 23.22 & 26.68 & 24.40 \\
5 & 25.16 & 23.88 & 26.16 & 24.21 \\
AVG & 25.51 & $23.56 \mathrm{kN} / \mathrm{m} 3$ & $26.51 \mathrm{kN} / \mathrm{m} 3$ & $24.51 \mathrm{kN} / \mathrm{m} 3$ \\
\hline
\end{tabular}

The results of the Schmidt hammer rebound hardness are shown in Tables $5-8$ while Table 9 is the Uniaxial Compressive Strength (UCS) and Tensile strength values.

Table 5. Schimidt Hammer Hardness Test Result (Type N Hammer).

\begin{tabular}{lllll}
\hline Test No & Obajana & Ewekoro I & Ewekoro II & Ewekoro III \\
\hline 1 & 39 & 36 & 25 & 37 \\
2 & 42 & 18 & 26 & 38 \\
3 & 31 & 34 & 40 & 19 \\
4 & 39 & 19 & 44 & 39 \\
5 & 41 & 36 & 46 & 30 \\
6 & 20 & 31 & 45 & 40 \\
7 & 39 & 37 & 31 & 28 \\
8 & 46 & 25 & 38 & 39 \\
9 & 45 & 37 & 29 & 31 \\
10 & 28 & 39 & 29 & 41 \\
11 & 36 & 23 & 48 & 35 \\
12 & 38 & 34 & 49 & 30 \\
13 & 34 & 29 & 50 & 25 \\
14 & 43 & 36 & 33 & 27 \\
15 & 31 & 35 & 35 & 33 \\
16 & 26 & 30 & 39 & 24 \\
17 & 41 & 17 & 48 & 31 \\
18 & 25 & 37 & 45 & 42 \\
19 & 40 & 25 & 47 & 42 \\
20 & 39 & 35 & 46 & 41 \\
\hline
\end{tabular}

Table 6. descending Values of Schmidt Rebound Hardness.

\begin{tabular}{llllll}
\hline & S/N & Obajana & Ewekoro I & $\begin{array}{l}\text { Ewekoro } \\
\text { II }\end{array}$ & $\begin{array}{l}\text { Ewekoro } \\
\text { III }\end{array}$ \\
\hline & 1 & 46 & 39 & 50 & 42 \\
& 2 & 45 & 37 & 49 & 42 \\
Upper & 3 & 43 & 37 & 48 & 41 \\
50\% & 4 & 42 & 37 & 48 & 41 \\
Values & 5 & 41 & 36 & 47 & 40 \\
Avera & 6 & 41 & 36 & 46 & 39 \\
ged & 7 & 40 & 36 & 46 & 39 \\
& 8 & 39 & 35 & 45 & 38 \\
& 9 & 39 & 35 & 45 & 37 \\
& 10 & 39 & 34 & 44 & 35 \\
& 11 & 39 & 34 & 40 & 33 \\
& 12 & 38 & 31 & 39 & 31 \\
Lower & 13 & 36 & 30 & 38 & 31 \\
$50 \%$ & 14 & 34 & 29 & 35 & 30 \\
values & 15 & 31 & 25 & 33 & 30 \\
Discar & 16 & 31 & 25 & 31 & 28 \\
ded & 17 & 28 & 23 & 29 & 27 \\
& 18 & 26 & 19 & 29 & 25 \\
& 19 & 25 & 18 & 26 & 24 \\
& 20 & 20 & 17 & 25 & 19 \\
\hline
\end{tabular}

Table 7. Upper 50\% Values of Schmidt Rebound Hardness and their Averages.

\begin{tabular}{lllll}
\hline S/N & Obajana & Ewekoro I & Ewekoro II & Ewekoro III \\
\hline 1 & 46 & 39 & 50 & 42 \\
2 & 45 & 37 & 49 & 42 \\
3 & 43 & 37 & 48 & 41 \\
4 & 42 & 37 & 48 & 41 \\
5 & 41 & 36 & 47 & 40 \\
6 & 41 & 36 & 46 & 39 \\
7 & 40 & 36 & 46 & 39 \\
8 & 39 & 35 & 45 & 38 \\
9 & 39 & 35 & 45 & 37 \\
10 & 39 & 34 & 44 & 35 \\
Avera & 41.5 & 36.2 & 46.8 & 39.4 \\
ge & & & & \\
\hline
\end{tabular}

Table 8. Conversion of Type N Schmidt Hammer values to Type L Values.

\begin{tabular}{lll}
\hline Samples & N Values & L Values \\
\hline Obajana & 41.5 & 35.1327 \\
Ewekoro I & 36.2 & 29.8327 \\
Ewekoro II & 46.8 & 40.4327 \\
Ewekoro III & 39.4 & 33.0327 \\
\hline
\end{tabular}

Table 9. UCS, Point Load Values and their Rock Class.

\begin{tabular}{llll}
\hline Samples & UCS (Mpa) & Is (Mpa) & Rock Class \\
\hline Obajana & 69.04 & 2.92 & High to Very High Strength \\
Ewekoro I & 47.91 & 1.92 & High Strength \\
Ewekoro II & 96.00 & 4.18 & Very High Strength \\
Ewekoro III & 58.70 & 2.43 & High to Very High Strength \\
\hline
\end{tabular}




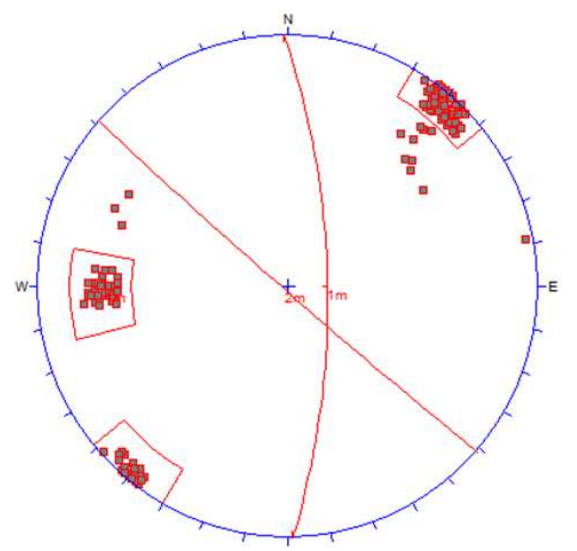

(a)

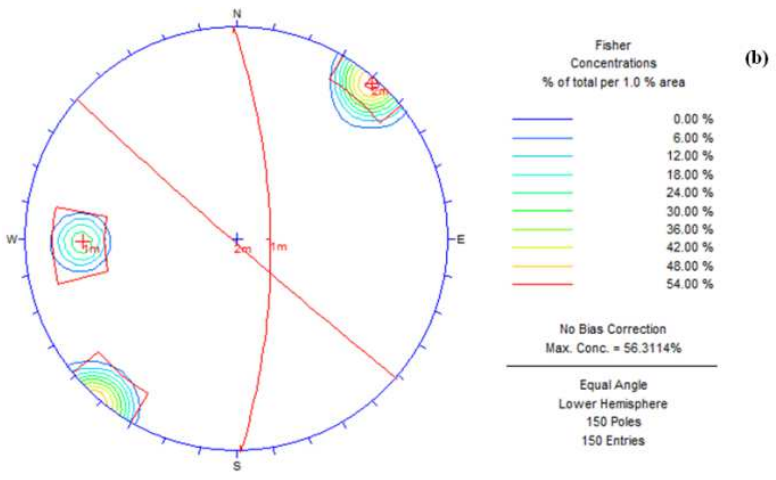

Figure 3. (a) Pole Plot (b) Contour plot of Obajana Quarry Face.
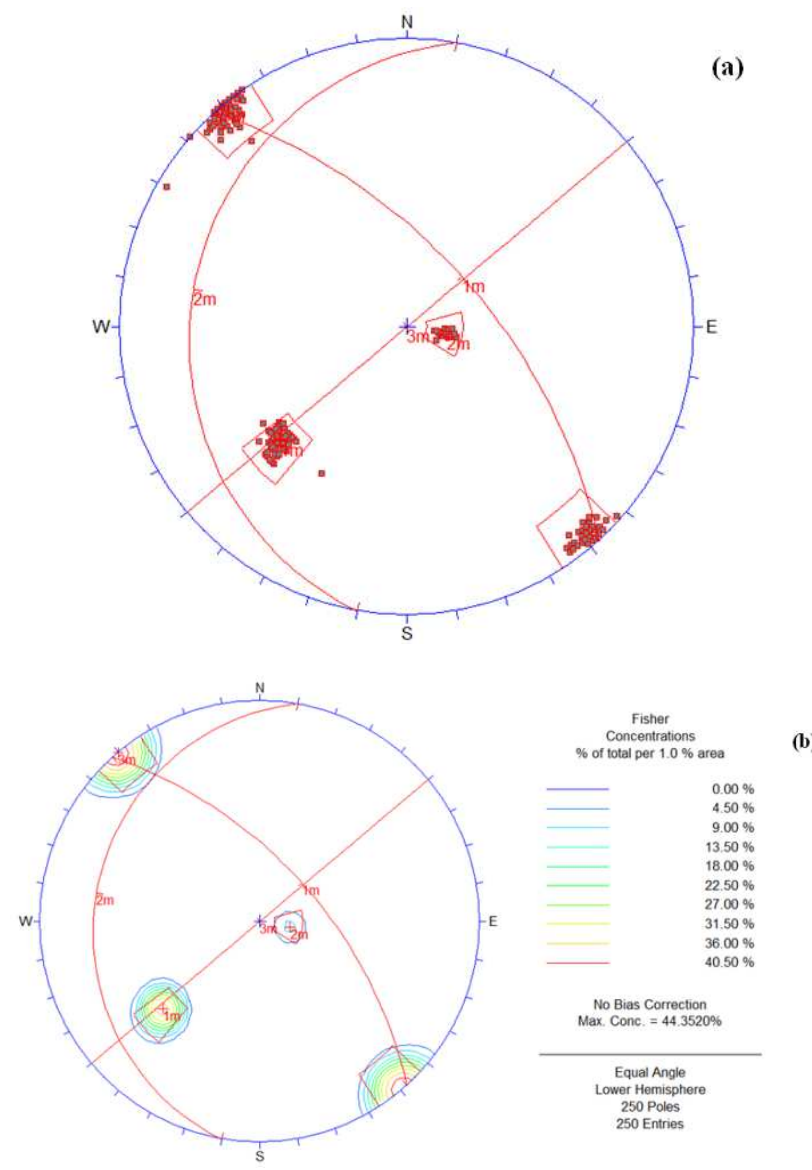

Figure 4. (a) Pole Plot (b) Contour plot of Ewekoro Quarry Face.

\subsection{Stability Analyses}

Based on kinematic considerations and frictional properties of joint planes, stability analyses were performed for each of the three quarry faces to see the potentials of toppling, planar sliding and wedge sliding on a stereonet using Dips 5.0 designed by Rocscience (1999). The results of each of the analyses are displayed in Figures 5 to 10 .

In the analyses, friction angle of approximately $29^{\circ}$ for Obajana and Ewekoro as obtained from RocLab was used for the friction cone. The measured orientations of the slope faces are 89/100 and 88/110 for Obajana and Ewekoro respectively.

The results show that there is no possibility of toppling failure in Obajana Quarry Face though plane and wedge failures are possible. The three failure modes (Toppling, planar and Wedge) were identified in Ewekoro.

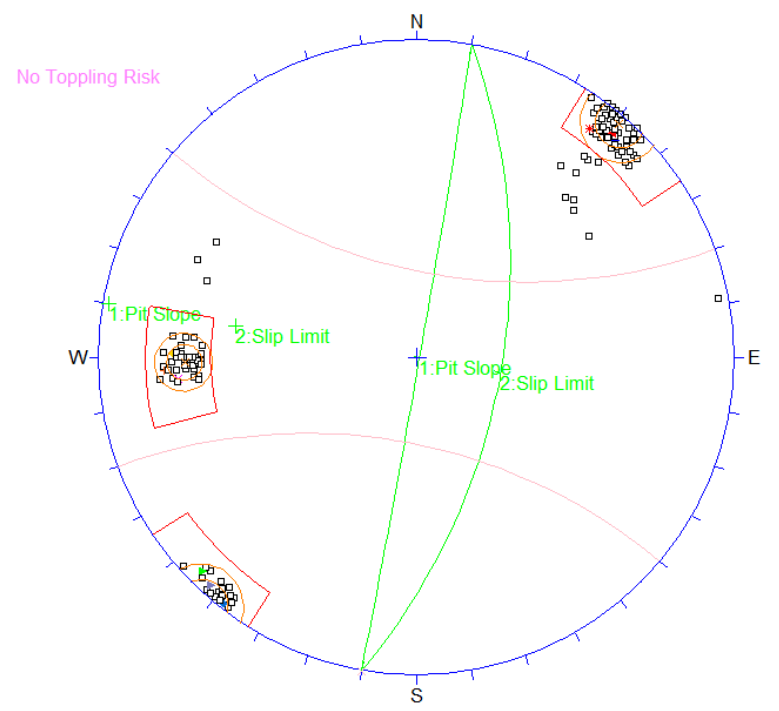

Figure 5. Toppling Analysis for Obajana.

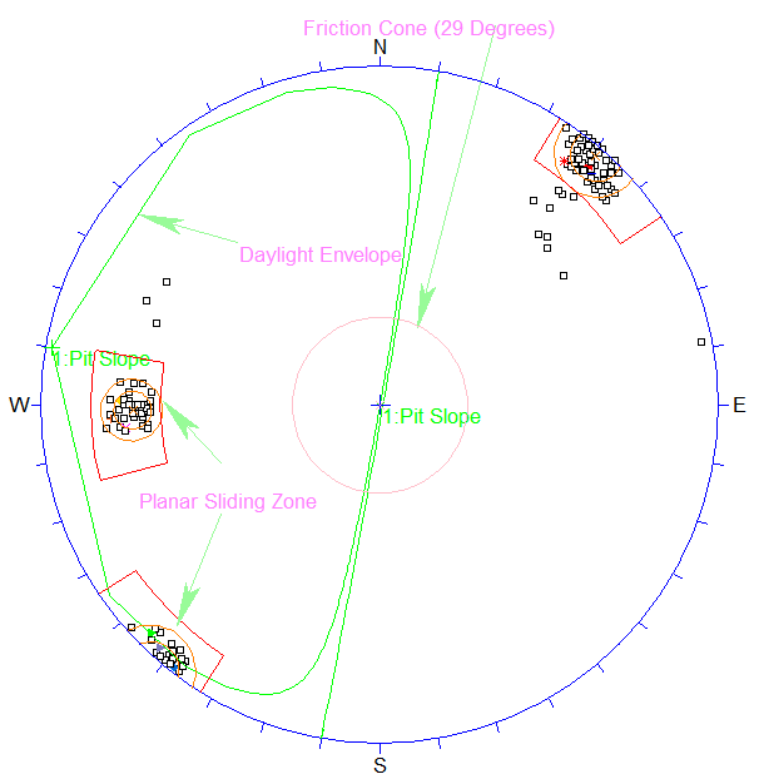

Figure 6. Planar Analysis for Obajana. 


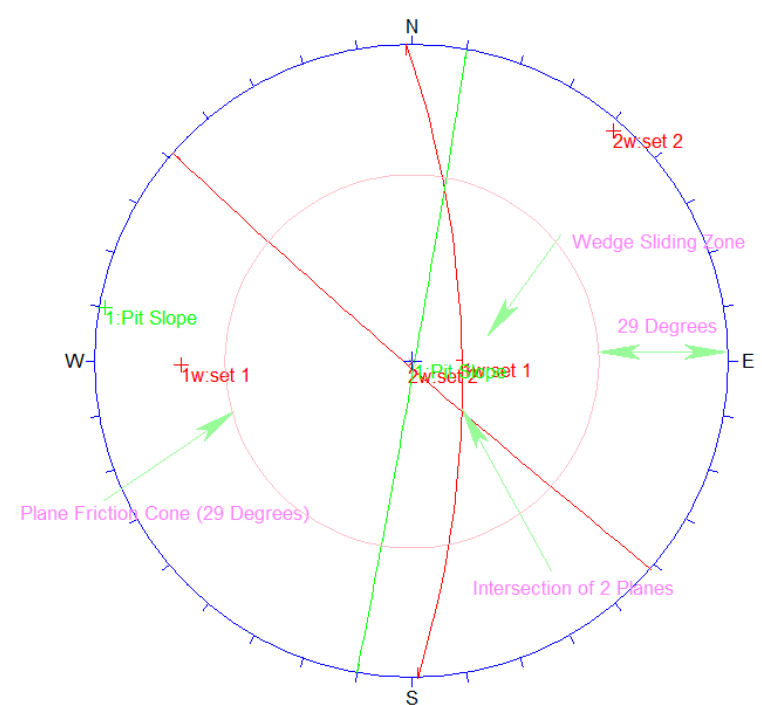

Figure 7. Wedge Analysis for Obajana.

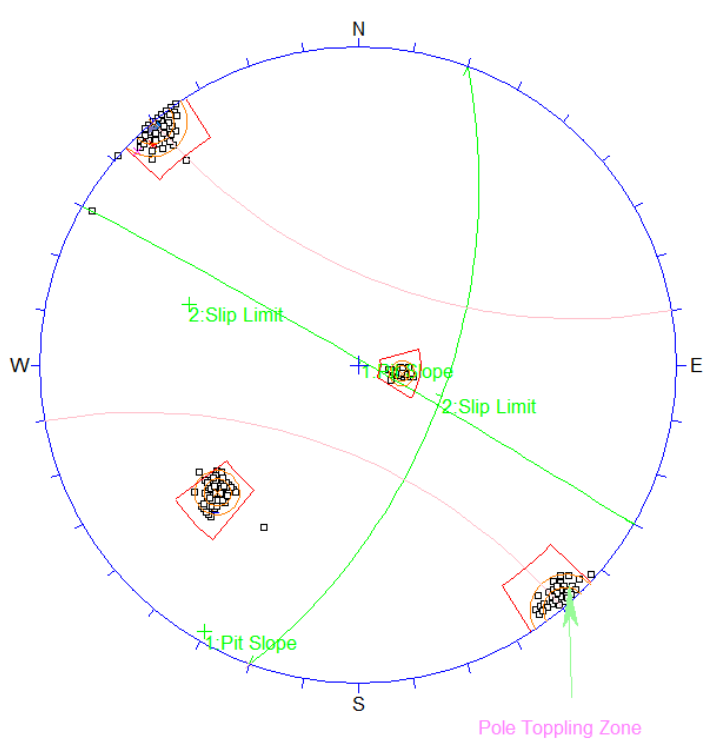

Figure 8. Toppling Analysis for Ewekoro.

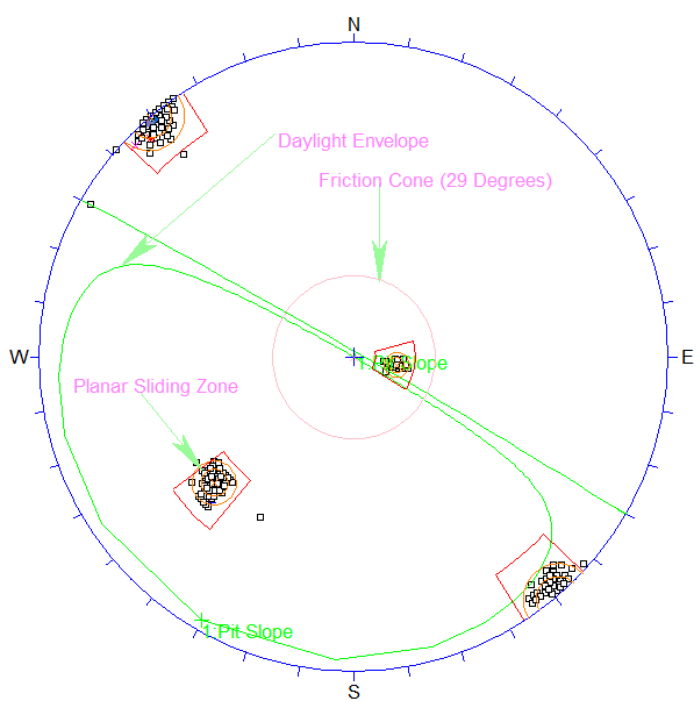

Figure 9. Planar Analysis for Ewekoro.

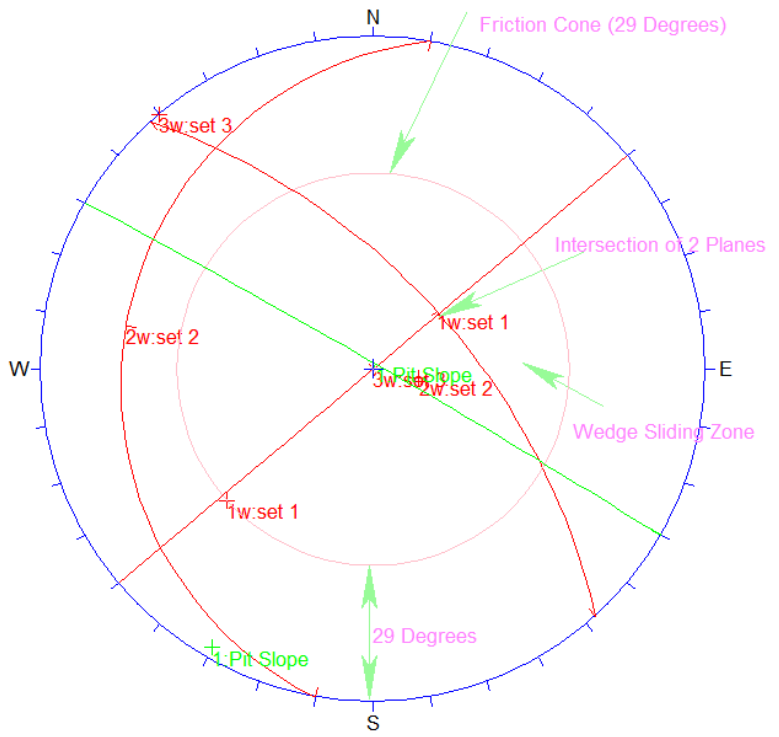

Figure 10. Wedge Analysis for Ewekoro.

\section{Conclusion}

Slope stability analyses of the quarry faces have been carried out. The research work shows that the orientations of discontinuities and rock strength parameters have pronounced effects on the overall state of stability of a quarry face.

\section{Recommendations}

1. There is an urgent need to reduce the face angles of the two quarries from the current $89^{\circ}$ or $88^{0}$ to about $60^{\circ}$ to $70^{\circ}$ in order to reduce the potentials of failures as evident from the kinematic analysis.

2. The bench heights should not be more than $10 \mathrm{~m}$ for both companies.

3. Periodic assessment of slope stability should be done to identify any potential failure and remediation measure initiated immediately.

4. Intensive dewatering of the faces should be carried out to reduce the effects of water on the overall slope stability. The right method can be obtained by carrying out Hydraulic Conductivity and Pump tests.

5. Further study is necessary to carry out the limit equilibrium and numerical analyses of the quarry faces investigated.

\section{References}

[1] Akande, J.M. and Idris, M.A. (2007). Mechanism of rock slope failure in selected quarries in Oyo sate, Nigeria: Advanced Materials Research, Trans Tech Publications, Switzerland, Vol. 18-19, pp. 13 - 19

[2] American Society for Testing Materials (ASTM), (1994). Annual Book of ASTM Standards-construction: Soil and Rocks. ASTM Publication, Vol. 04.08.978, p. 975 
[3] Aydin, A. and Basu, A. (2005). The Schmidt hammer in rock material characterization: Journal of Engineering Geology, 81 (2005), Elsivier International, pp. 1-14.

[4] Eberhardt, E. (2003). Rock slope stability analysis utilization of advanced numerical techniques, Vancouver, Canada: Earth and Ocean Sciences, University of British Columbia. Retrieved on $23^{\text {rd }}$ August, 2010 from www.eos.ubc.ca/personal/erik/e-paper, p. 41

[5] Goodman, R.E. (1980). Introduction to Rock mechanics: John Wiley and Sons, New York, p. 478

[6] Goodman, R.E. and Bray, J.E. (1976). Toppling of rock slopes: Proceedings of speciality conference on rock engineering for foundations and slopes, Colorado, Vol. 02, pp. $201-243$.

[7] Goodman, R.E., (1989). Introduction to Rock Mechanics (2nd edition): Wiley, New York, p. 562

[8] Gurocak, Z., Alemdag, S. and Zaman, M.M. (2008). Rock slope stability and excavatability assessment of rocks at the Kapikaya dam site, Turkey: Journal of Engineering Geology, vol. 96(1-2): pp. 17-27.

[9] Hoek, E. and Bray, J.W. (1981). Rock Slope Engineering ( ${ }^{\text {rd }}$ edition): The Institution of Mining and Metallurgy, London, p. 358
[10] International Society for Rock Mechanics, ISRM. (1981). Rock characterization, testing and monitoring. In: Brown, E.T. (edition) ISRM suggested methods. Pergamon Press, Oxford, UK, p. 211.

[11] Kliche, C. A. (1999). Rock Slope Stability: Society for Mining, Metallurgy, and Exploration, Colorado, USA, p. 253

[12] Pettifer, G.S. and Fookes, P.G. (1994). A revision of the graphical method for assessing the excavatability of rock: Quarterly Journal of Engineering Geology 27, pp. 145-164.

[13] Rocscience Ltd. (1999). DPS 5.0 software for graphical and statistical analysis of orientation based geological data. Toronto, Ontario, Retrieved on $23^{\text {th }}$ July, 2011 from www.rocscience.com.

[14] Rocscience Ltd. (2002). ROCLAB software for calculating Hoek - Brown Rock mass Strength. Toronto, Ontario, Retrieved on $16^{\text {th }}$ July, 2011 from www.rocscience.com

[15] Wyllie, D.C. and Mah, C.W. (2005). Rock Slope Engineering: civil and mining ( $4^{\text {th }}$ Edition): Spon Press, Taylor and Francis Group, London and New York, p. 431

[16] Xu, S., Grasso, P. and Mahtab, A. (1990). Use of Schmidt Hammer for estimating mechanical properties of weak rock: Proc. $6^{\text {th }}$ International IAEG Congress, vol. 1. Balkema, Rotterdam, pp. $511-519$. 